\title{
Fluorine F 18-AV-133
}

National Cancer Institute

\section{Source}

National Cancer Institute. Fluorine F18-AV-133. NCI Thesaurus. Code C116356.

A radioconjug ate composed of the vesicular monoamine transporter 2 (VMAT2) targeting agent AV-133, a dihydrotetrabenazine analog, labeled with the positronemitting isotope fluorine $F 18$, that can potentially be used as a tracer using positron emitting tomography (PET) imaging. Upon administration, the AV-133 moiety of fluorine F 18-AV-133 binds to VMATs expressed on monoamine neurons and pancreatic betacells within the islets of Langerhans. Upon PET imaging, VMAT2-expressing cells can be detected and the level of functional monoamine neurons can be assessed, which can be used in the diagnosis of neurodegenerative diseases. In addition, this radiotracer can be used to assess the function of pancreatic beta-cells. VMAT 2, a transporter that loads monoamine neurotransmitters into secretory vesicles, is expressed on biogenic aminecontaining neurons in the central nervous system (CNS) and pancreatic beta cells. 